\title{
Growth of Brachiaria decumbens in Latosol contaminated with copper
}

\section{Crescimento de Brachiaria decumbens em Latossolo contaminado com cobre}

\author{
Ilmo Correia Silva ${ }^{1}$, Cleonice Rocha ${ }^{2}$, Mariella Camargo Rocha ${ }^{1}$, Cleiton Mateus Sousa ${ }^{1 \star}$
}

IInstituto Federal Goiano/IF Goiano, Ceres, GO, Brasil

2Pontifícia Universidade Católica de Goiás/PUC Goiás, Goiânia, GO, Brasil

*Corresponding author: sousacm@yahoo.com.br

Received in November 9, 2017 and approved in April 23, 2018

\begin{abstract}
Brachiaria decumbens presents high rusticity, rapid growth, as well as easy implantation and management. The aim of the study is to evaluate the growth of brachiaria in soil contaminated with copper. An experiment following a $3 \times 4$ factorial design was carried. It comprised three plant ages (30, 45 and 60 days after transplanting) and four copper concentrations ( $0,20,40$ and $80 \mathrm{mg}$ of Cu per kg of soil). Plant age and copper concentrations have influenced the main pseudostem length, the number of leaves, as well as the leaf area, chlorophyll (SPAD), fresh and dry shoot matter, root system volume, and fresh and dry root system matter of plants. The lowest dry shoot matter accumulation was found at the concentration $51.24 \mathrm{mg} \mathrm{Kg}^{-1}$. The herein investigated copper concentrations have influenced the growth of Brachiaria decumbens. The lowest growth variable values were between 45.52 and $57.63 \mathrm{mg}$.Kg-1. Thus, brachiaria has shown potential to be used in Copper phytoremediation at concentrations below $45.52 \mathrm{mg} \mathrm{Kg}^{-1}$.
\end{abstract}

Index terms: Adsorption; Cerrado; phytoremediation; heavy metal.

\section{RESUMO}

A Brachiaria decumbens apresenta alta rusticidade, crescimento rápido, facilidade na implantação e manejo. Avaliou-se o crescimento de braquiária em solo contaminado com cobre. Implantou-se um experimento em arranjo fatorial 3 x 4, sendo três idades das plantas (30; 45 e 60 dias após o transplante) e quatro dosagens de cobre (0; 20; 40 e 80 mg de Cu por kg de solo). A idade das plantas e as doses de cobre influenciaram no comprimento do pseudocolmo principal, número de folhas, área foliar, clorofila (SPAD), massa fresca e seca da parte aérea, volume do sistema radicular, e massa fresca e seca do sistema de radicular de plantas de Brachiária. O menor acúmulo de massa seca da parte aérea de plantas foi obtido da concentração de 51,24 mg Kg-1. A Brachiaria decumbens demonstrou tolerância e potencial de cultivo em solos contaminados com cobre.

Termos para indexação: Adsorção; Cerrado; fitorremediação; metal pesado.

\section{INTRODUCTION}

Copper is one of the oldest known metals and the twenty-fifth most abundant element in the earth's crust. It is also a good electricity conductor. Copper was defined as essential to vegetables in 1930; however, high copper concentrations cause toxicity, mainly in plant roots (Kopsell; Kopsell, 2007).

Agricultural and industrial activities may increase the amount of copper in the soil, fact that may change the microorganism population, the biological activity (Li et al., 2016), and consequently, the soil productive capacity. When it comes to plants, $\mathrm{Cu}$ is associated with the transport of electrons between membranes during the photosynthetic process; it is found complexed with proteins and, when it is available in its free form, it produces free radicals with high oxidation capacity, damages cell membranes (Williams, 2015) and inhibits electron transport and primary metabolism. Overall, the excess of copper reduces plant growth, the number and thickness of roots, and biomass accumulation. However, many plants have defense mechanisms comprising the expression and activation of antioxidative enzymes, as well as the formation of chelating agents due to heavy metals. Plants also range from highly sensitive to tolerant to heavy metal accumulation (Ovečka; Takáč, 2014).

Currently, there are two prevailing segments able to minimize the impact heavy metals have on the soil. The first segment concerns the ability of each species to absorb the heavy metals available in the soil through phytoextraction and phytoremediation. The second one refers to plants' resistance to toxicity, which allows them to grow and produce even in soils containing high contaminant concentrations (Carmo et al., 2008).

According to studies about heavy metal remediation mechanisms, the use of Brachiaria decumbens may be an 
interesting alternative to identify and select copper-tolerant plants, because the species presents good biomass yield, tolerance to acidic soils (Arroyave et al., 2013), easy implantation, rapid growth, high photosynthetic efficiency, and efficient use of nutrients. The species may be even intercropped with other annual or perennial crops.

Santos et al. (2006) have highlighted that Brachiaria decumbens meets the requirements to be used in cadmium $(\mathrm{Cd})$, zinc $(\mathrm{Zn})$ and lead $(\mathrm{Pb})$ phytoextraction due to its rapid growth, biomass accumulation and tolerance to aluminum. Thus, it is worth assessing the tolerance of plants adapted to Cerrado conditions to $\mathrm{Cu}$ levels in the soil, since there are no studies about species with aggressive growth behavior and adapted to Cerrado conditions, such as brachiaria plants. Santos et al. (2015) found that the cultivation of eucalyptus with Brachiaria between lines showed better results for recovery of soil contaminated with heavy metals.

The aim of the current study is to assess the growth of Brachiaria decumbens in latosol contaminated with copper.

\section{MATERIAL AND METHODS}

The current study was carried out from September to December 2015, in a greenhouse belonging to Instituto Federal Goiano (Goiano Federal Institute) - Campus Ceres, Ceres County - Goiás State, located at the geographic coordinates $15^{\circ} 21^{\prime} 18.65$ "S and 49 36'26.26" W, 600 $\mathrm{m}$ altitude. The soil used in the experiment was medium texture red latosol. The region has tropical semi-humid climate and mean temperature $28^{\circ} \mathrm{C}$.

The soil used in the current study was collected at Goiano Federal Institute - Campus Ceres, and it showed the following chemical and physical properties: $69.8 \%$ sand; $8.4 \%$ silt and $21.8 \%$ clay; $\mathrm{pH}$ (in water) $=7.0$; O.M. $=14.2 \mathrm{~g} \mathrm{~m}^{-3}$ (colorimetric); $\mathrm{P}=160.0 \mathrm{mg} \mathrm{dm}^{-3}, \mathrm{~K}=$ $1.0 \mathrm{cmolc} \mathrm{dm}^{-3}, \mathrm{Cu}=1.7 \mathrm{mg} \mathrm{kg}^{-1}$ (Mehlich-1); $\mathrm{Ca}=4.1$ cmolc dm ${ }^{-3}, \mathrm{Mg}=1.8$ cmolc dm $^{-3}\left(\mathrm{KCl} \mathrm{mol.1}{ }^{-1}\right) ; \mathrm{H}^{+} \mathrm{Al}=$ $0.0 \mathrm{cmolc} \mathrm{dm}^{-3}$ (SMP buffer at $\left.\mathrm{pH} 7.5\right)$; CTC $=7.9$ and $\mathrm{V}$ $=87.3 \%$. The methodology used in all soil analyses has followed the recommendations by EMBRAPA (2011). The analyses were carried out at Goiano Federal Institute Soil Laboratory - Ceres Campus. The preparation of the collected soil was based on drying the samples in open air for physical and chemical analysis purposes. The clods were crushed and the samples were sieved in a $2 \mathrm{~mm}$ mesh to obtain the air-dried fine earth (ADFE).

The $\mathrm{pH}$ values were obtained by electronically measuring the Hydrogen potential using a combined electrode immersed in soil: water suspension $(1: 2.5)$. The solution was based on $10 \mathrm{~cm}^{3}$ ADFE, using a $25 \mathrm{ml}$ water dosing scoop in a $50 \mathrm{ml}$ beaker. It was stirred in a TECNAL Te-145 horizontal stirrer (orbital stirring table) at $180 \mathrm{rpm}$, for 5 minutes. A glass stick was used to stir the sample after 30 minute rest and the reading was carried out in a LOGEN LS-300 HH potentiometer with combined electrode.

The $\left(\mathrm{H}^{+} \mathrm{Al}\right)$ estimate and the soil acidity extraction used buffered calcium acetate determined through combined electrode immersed in $0.01 \mathrm{moL}^{-1}$ buffered $\mathrm{CaCl}_{2}$ solution. The reading was performed in a potentiometer with combined electrode and, at the end, a table was used to estimate the $\mathrm{H}^{+} \mathrm{Al}$ values.

The total fraction of phosphorus content in the soil corresponded to the content used by the plants. The extraction was based on $5 \mathrm{~cm}^{3} \mathrm{ADFE}$ and $50 \mathrm{~mL}$ Mehlich-1 extracting solution $\left(0.05 \mathrm{moL}^{-1} \mathrm{HCl}+0.0125 \mathrm{moL}^{-1}\right.$ $\mathrm{H}_{2} \mathrm{SO}_{4}$ ). After the sample was left to rest for at least $16 \mathrm{~h}, 5$ $\mathrm{mL}$ of working reagent was added to it and the phosphorus content was estimated in the BEL Photonice UV/Vis spectrophotometer, Model LGS 53, with wavelength 730 $\mathrm{nm}$ and frequency 50.

The potassium estimate was based on $5 \mathrm{~cm}^{3}$ ADFE and $50 \mathrm{ml}$ Mehlich-1 extracting solution. The reading was carried out in the Analiser flame photometer, Model $910 \mathrm{MS}$.

The organic matter (O.M.) estimate was based on 1 $\mathrm{cm}^{3} \mathrm{ADFE}$ and $10 \mathrm{~mL}$ digesting solution $\left(\mathrm{Na}_{2} \mathrm{Cr}_{2} \mathrm{O}_{7} \cdot 2 \mathrm{H}_{2} \mathrm{O}\right.$ $\left.+\mathrm{H}_{2} \mathrm{SO}_{4}\right)$. The reading was performed in the BEL Photonice UV/Vis Spectrophotometer, Model LGS 53.

The $\mathrm{Ca}$ and $\mathrm{Mg}$ estimates were based on $5 \mathrm{~cm}^{3}$ ADFE and $50 \mathrm{ml}$ of $1 \mathrm{~mol}^{-1} \mathrm{KCl}$ extracting solution. The solution was stirred and left to rest for at least 16 hours; after this period, a $1 \mathrm{ml}$ aliquot of the supernatant was added with $17 \mathrm{ml}$ of $\mathrm{La}_{2} \mathrm{O}_{3}$ solution at $0.1 \%$. The $\mathrm{Ca}$ and $\mathrm{Mg}$ were estimated in a GBC atomic absorption spectrophotometer, model SAVANT AA.

The Al estimate was based on $5 \mathrm{~cm}^{3} \mathrm{ADFE}$ and 50 $\mathrm{ml}$ of $1 \mathrm{moL}^{-1} \mathrm{KCl}$ extracting solution. After the solution was left to rest for at least 16 hours, it was titrated with $0.025 \mathrm{moL}^{-1} \mathrm{NaOH}$ using bromothymol blue.

The textural analysis used the pipet method and it was based on $10 \mathrm{~cm}^{3}$ ADFE and $50 \mathrm{ml} \mathrm{NaOH}$. After the solution was stirred and left to rest for at least 16 hours, it was transferred to a $1000 \mathrm{~mL}$ beaker and topped with distilled water. Subsequently, it was stirred and left to rest for 4 minutes. The temperature of $25 \mathrm{~mL}$ suspension was measured and the sedimentation time of the fractions was calculated.

The contamination was carried out through soil spraying with copper sulfate pentahydrate solution $\left(\mathrm{CuSO}_{4} .5 \mathrm{H}_{2} \mathrm{O}\right)$ at the concentrations $0,20,40$ and $80 \mathrm{mg} \mathrm{Kg}^{-1}$; a cement mixer was used to homogenize the $\mathrm{Cu}$ in the soil. The contaminated soil was distributed in $5.0 \mathrm{~L}$ plastic containers. 
Brachiaria seedlings were produced in a 128 cell polystyrene tray filled with commercial substrate using Brachiaria decumbens seeds produced by the company "Sementes Moeda" - Quirinópolis - GO and sold by the local stores. After the seedlings presented four leaves, approximately fifteen days after sowing, they were transferred to the pots containing the contaminated soil and kept in a greenhouse under micro sprinkler irrigation at two-hour intervals, during the experimental period.

The experiment has followed a randomized complete block design comprising a $3 \times 4$ factorial arrangement, three plant ages (30,45 and 60 days after transplantation), four copper concentrations $\left(0,20,40\right.$ and $\left.80 \mathrm{mg} \mathrm{kg}^{-1}\right)$ and four repetitions.

The number of tillers and leaves, the leaf area, the pseudostem length, the longest root length, the root system volume, the chlorophyll in the leaves, the fresh and dry shoot matter, and the fresh and dry root system matter were assessed in each collection.

An analytical scale (Shimadzu AY Precision Series) with $220 \mathrm{~g}$ capacity and $0.0001 \mathrm{~g}$ accuracy - Inmetro certification - was used to measure the fresh shoot and root matters. The roots were separated from the soil (through washing), and weighed and measured after the water was drained.

ACID INC laser meter, model CI-203 (Bio-Science ${ }^{\circledR}$, Camas, WA, USA) was used to measure the leaf area, whereas the chlorophyll content (SPAD) was measured in a Minolta portable chlorophyll meter, Mod. SPAD 502 (Soil and Plant Analysis Development).
The data were subjected to ANOVA; the means of the assessment period were compared through Tukey test at $5 \%$ error probability. A linear regression analysis was carried out to find the plants' response tendencies according to the copper concentrations, which should be explained through the quadratic polynomial linear equation.

\section{RESULTS AND DISCUSSION}

The copper concentrations and the plant age have influenced the number of leaves, leaf area, pseudostem length, root system volume, chlorophyll (SPAD), fresh and dry shoot matter, and fresh and dry root system matter. On the other hand, the number of tillers was influenced by the interaction between copper concentrations and sampling times. The pseudostem length, root system volume, fresh and dry shoot matter, and dry root system matter have increased as the plants grew older (Table 1). However, the chlorophyll has shown reversed response (Table 2).

Santos et al. (2011) have estimated the life span of Brachiaria decumbens leaves in 37.8 days. According to Bianco et al. (2000), the biomass accumulation has increased for 160 days after the plants emerged. It has reached $38.27 \mathrm{~g}$ of total dry matter and $9.67 \mathrm{~g}$ of leaves per plant. Brachiaria plants have continuous and indeterminate growth; new leaves emerge simultaneously to the senescence of the older leaves. The dry matter of the plants was higher than that found by Bianco et al. (2010). By considering the growth

Table 1: Fresh shoot matter (FSM), dry shoot matter (DSM), fresh root system matter (FRSM) and dry root system matter (DRSM) of Brachiaria decumbens plants at different ages, cultivated in soil contaminated with copper.

\begin{tabular}{ccccc}
\hline Plant's age (days) & $\begin{array}{c}\text { FSM } \\
(\mathrm{g})\end{array}$ & $\begin{array}{c}\text { DSM } \\
(\mathrm{g})\end{array}$ & $\begin{array}{c}\text { FRSM } \\
(\mathrm{g})\end{array}$ & $\begin{array}{c}\text { DRSM } \\
(\mathrm{g})\end{array}$ \\
\hline 30 & $31.33 \mathrm{c}$ & $6.44 \mathrm{c}$ & $38.02 \mathrm{~b}$ & $4.50 \mathrm{c}$ \\
45 & $55.49 \mathrm{~b}$ & $24.56 \mathrm{~b}$ & $81.15 \mathrm{a}$ & $14.63 \mathrm{~b}$ \\
60 & $77.28 \mathrm{a}$ & $36.86 \mathrm{a}$ & $81.27 \mathrm{a}$ & $30.23 \mathrm{a}$ \\
\hline
\end{tabular}

*Mean treatment values followed by the same letter in the column do not statistically differ from each other, according to the Tukey test, at $5 \%$ probability.

Table 2: Number of leaves, leaf area, chlorophyll (SPAD), main pseudostem length (MPSL), and root system volume (RSV) of Brachiaria decumbens plants at different ages, cultivated in soil contaminated with copper.

\begin{tabular}{cccccc}
\hline Plants' age (days) & Number of leaves & Leaf area $\left(\mathrm{cm}^{-2}\right)$ & $\begin{array}{c}\text { Chlorophyll } \\
\text { (SPAD) }\end{array}$ & $\begin{array}{c}\text { MPSL } \\
(\mathrm{cm})\end{array}$ & $\begin{array}{c}\text { RSV } \\
\left(\mathrm{cm}^{-3}\right)\end{array}$ \\
\hline 30 & $50.00 \mathrm{~b}$ & $571.33 \mathrm{~b}$ & $39.49 \mathrm{c}$ & $65.85 \mathrm{c}$ & $39.93 \mathrm{c}$ \\
45 & $60.43 \mathrm{~b}$ & $1064.01 \mathrm{ab}$ & $31.14 \mathrm{~b}$ & $86.19 \mathrm{~b}$ & $71.25 \mathrm{~b}$ \\
60 & $118.08 \mathrm{a}$ & $1548.01 \mathrm{a}$ & $22.64 \mathrm{a}$ & $100.90 \mathrm{a}$ & $110.00 \mathrm{a}$ \\
\hline
\end{tabular}

*Mean treatment values followed by the same letter in the column do not statistically differ from each other, according to the Tukey test, at $5 \%$ probability. 
dynamics of Brachiaria decumbens, Velasco (2011) has found that plants cut at 56 days presented better nutritive value than plants cut at 84 and 112 days.

According to Table 1, there was increased FSM, DSM and DRSM in all plant ages investigated in the current study. The increase rates in ages between 30 and 45 days were higher than those in ages between 45 and 60 days; they presented differences higher than $24 \%$.

There was increase in the number of leaves, leaf area, pseudostem length and root system volume according to the plants' age increase (Table 2). However, the chlorophyll content did not follow the same trend; it has shown approximately $21 \%$ decline in the age interval between 30 and 45 days and subsequent $27.3 \%$ decline in the age interval between 45 and 60 days.

Figures 1 to 8 show responses to variables such as the number of tillers, number of leaves, leaf area, shoot length, chlorophyll, fresh and dry shoot matter, root system volume, fresh and dry root system matter. The response trends for these variables are explained through the quadratic polynomial linear equation.

Figure 1 shows that older plants have shown greater sensitivity to copper concentrations. This fact may be associated with the $\mathrm{Cu}$ absorption during the time the plants were cultivated in contaminated soil. The lowest number of tillers was found in 30, 45 and 60-day-old plants at the concentrations $58.03,49.12$ and $40.30 \mathrm{mg} \mathrm{kg}^{-1}$, respectively.

The smallest number of leaves was found at the concentration $51.61 \mathrm{mg} \mathrm{kg}^{-1}$. There was positive correlation (0.82) between the number of leaves and the leaf area. Thus, concentrations above $51.61 \mathrm{mg} \mathrm{kg}^{-1}$ have reduced the number of leaves, compromised the leaf area and, consequently, compromised the production of photoassimilates and biomass accumulation in the plant.

Zanine and Vieira (2006) have reported that the number of leaves the grasses keep per tiller is relatively constant under adequate growth conditions, since the emergence of new leaves coincides with the death of the oldest ones. Thus, soils contaminated with $\mathrm{Cu}$ concentrations above $51.61 \mathrm{mg} \mathrm{kg}^{-1}$ (Figure 2) compromise the metabolism of brachiaria plants.

The lowest main pseudostem length was found at the concentration $45.52 \mathrm{mg} \mathrm{kg}^{-1}$ (Figure 3). The increased pseudostem length has favored the increase in the number of leaves and in leaf area, since there was 0.74 and 0.71 positive correlation between pseudostem length and number of leaves, as well as between pseudostem length and leaf area, respectively.

The lowest leaf area $\left(756.26 \mathrm{~cm}^{-2}\right)$ was found at the concentration $53.54 \mathrm{mg} \mathrm{kg}^{-1}$ (Figure 4). The leaf area accounts for the production of photoassimilates necessary to meet the metabolic demand and for the formation of new plant structures. Thus, the leaf area reduction led to reduction in fresh and dry shoot matter, with 0.83 and 0.75 positive correlation, respectively.

The lowest chlorophyll content (SPAD) was found at the concentration $38.23 \mathrm{mg} \mathrm{kg}^{-1}$ (Figure 5). According to Maranhão et al. (2009), nitrogen application has increased the chlorophyll content in SPAD values in Brachiaria decumbens. The authors have associated crude protein increase with dry matter production in plants showing increased chlorophyll content. They have also reported that the chlorophyll content (SPAD index) can be used as plant protein level indicator.

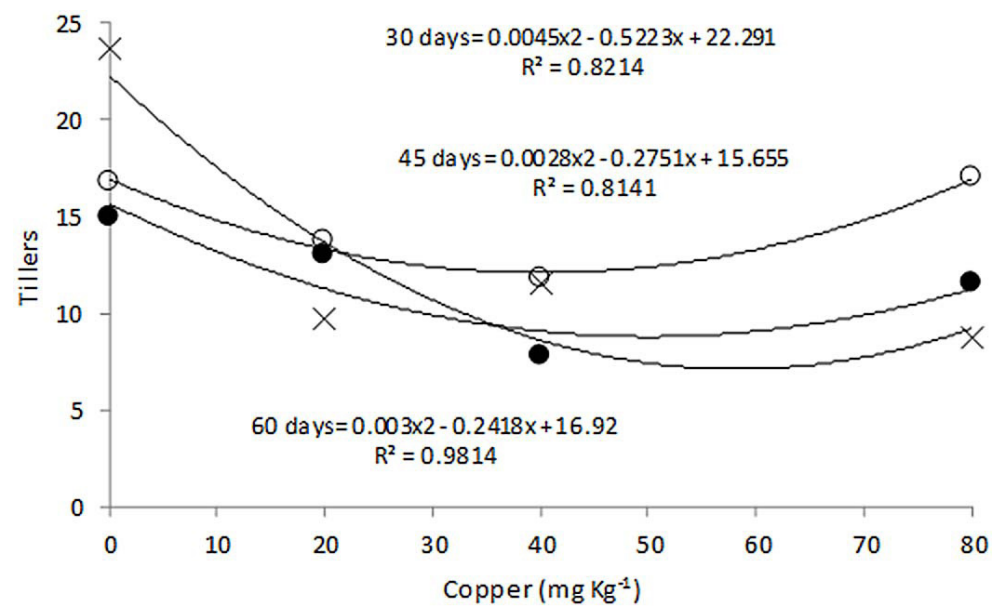

Figure 1: Number of tillers in Brachiaria decumbens plants cultivated in soil contaminated with copper ("X" 30 dayold plants; “•"45-day-old plants; and "O" 60-day-old plants). 


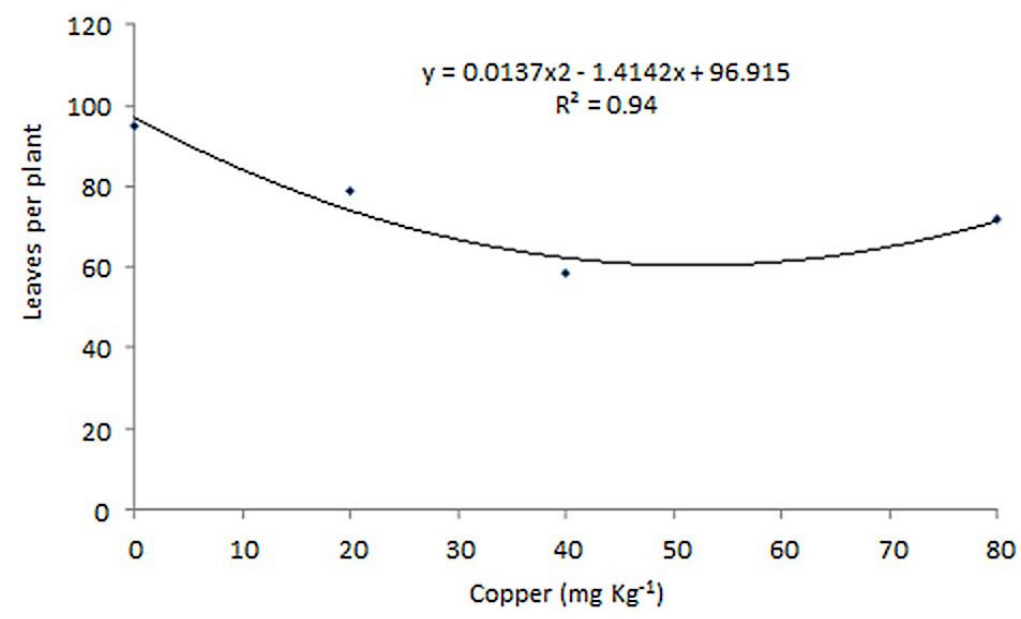

Figure 2: Number of leaves in brachiaria plants cultivated in soil contaminated with copper.

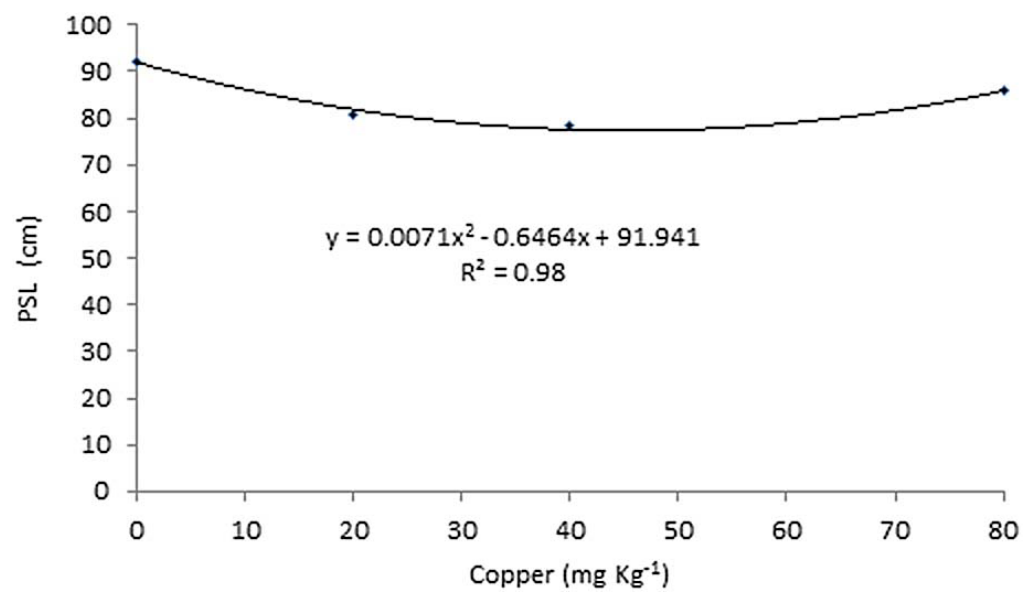

Figure 3: Pseudostem length (PSL) of brachiaria plants cultivated in soil contaminated with copper.

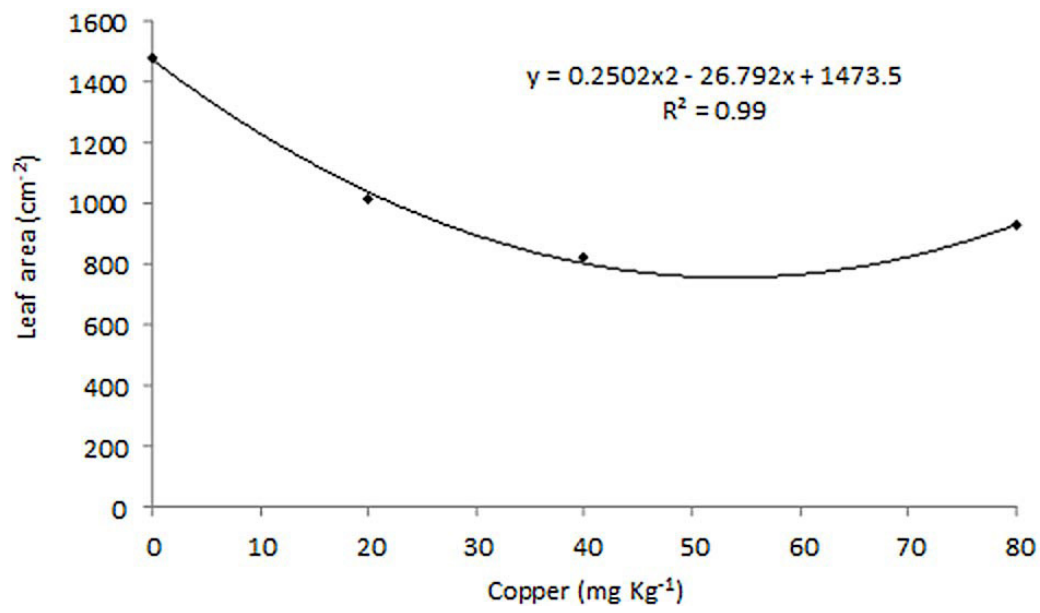

Figure 4: Leaf area of brachiaria plants cultivated in soil contaminated with copper. 


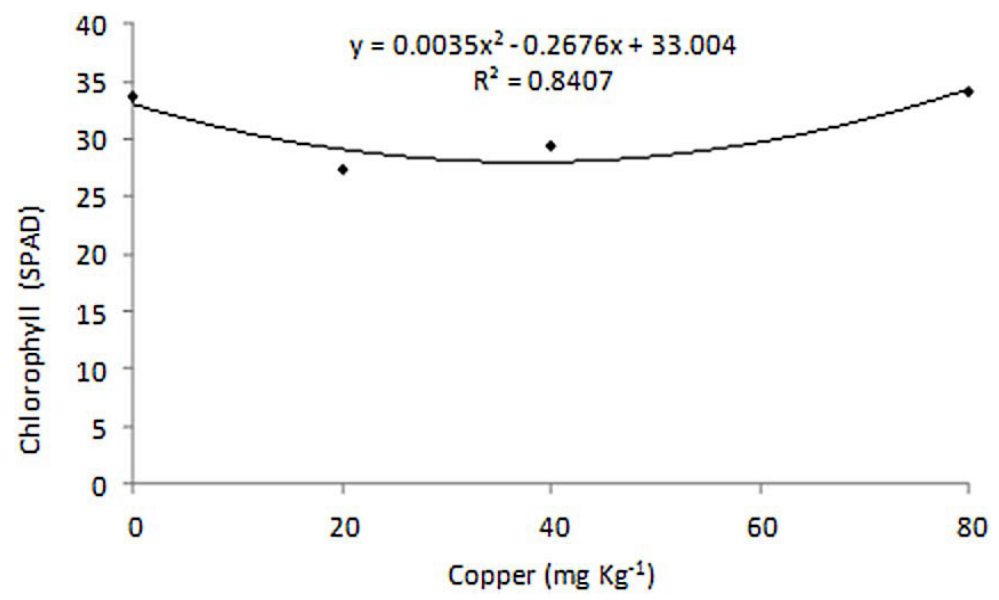

Figure 5: Relative chlorophyll content (SPAD) in leaves of brachiaria plants cultivated in soil contaminated with copper.

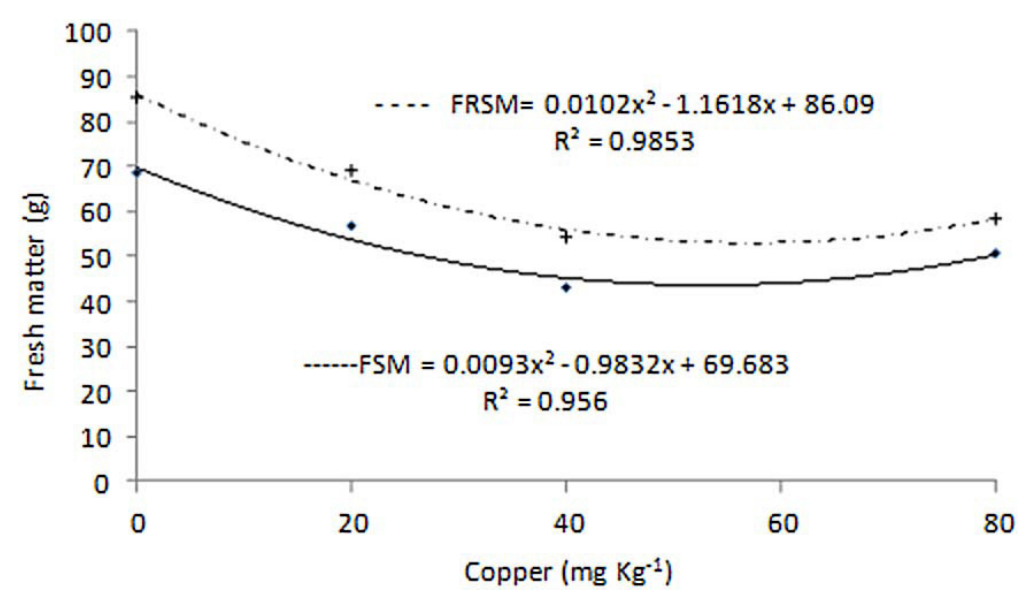

Figure 6: Biomass accumulation in the shoot and root system of brachiaria plants cultivated in soil contaminated with copper.

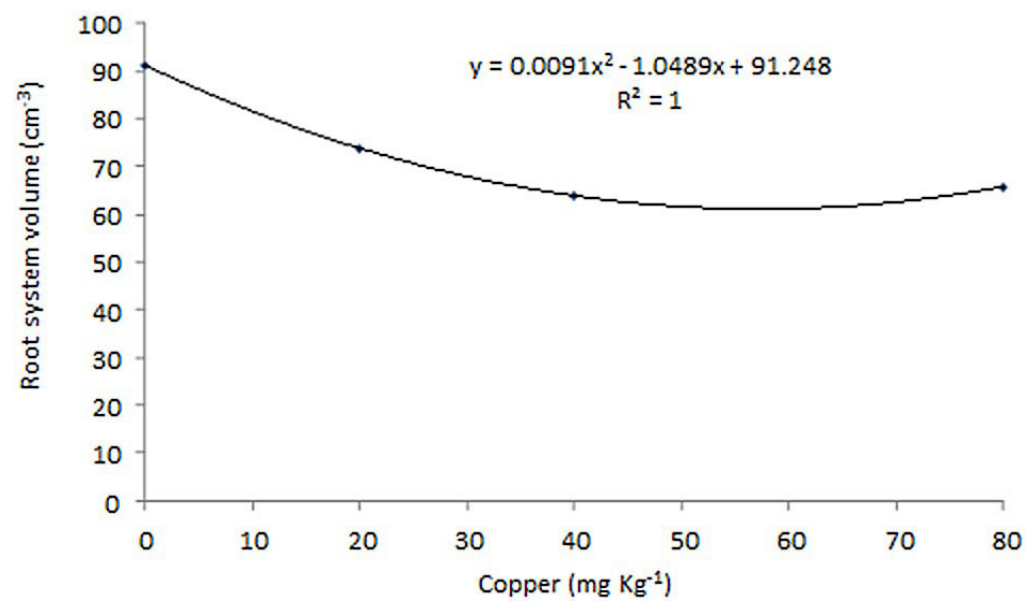

Figure 7: Root system volume $\left(\mathrm{cm}^{-3}\right)$ in brachiaria plants cultivated in soil contaminated with copper. 


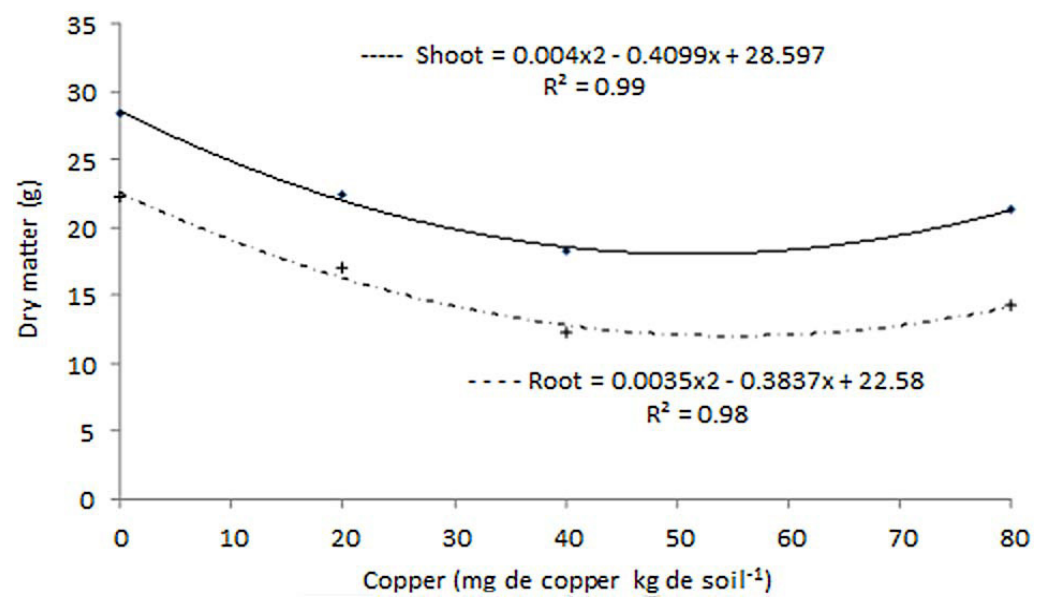

Figure 8: Biomass accumulation in the shoot and root system of brachiaria plants cultivated in soil contaminated with copper.

The lowest fresh shoot biomass of each plant (43.697 g) was found at the concentration $52.86 \mathrm{mg} \mathrm{kg}^{-1}$ and that of the root system $(53.007 \mathrm{~g})$ was found at the concentration $56.95 \mathrm{mg} \mathrm{kg}^{-1}$ (Figure 6). The reduced fresh shoot and root system biomass may be associated with the reduced production of photoassimilates, as well as with reduced leaf area in the plants and with the reduced chlorophyll content in the leaves, as shown in Figures 4 and 5 .

The lowest root system volume was found at the concentration $57.63 \mathrm{mg} \mathrm{kg}^{-1}$ (Figure 7). Plants show relation between the shoot and the root system. Such relation ensures balance in the production of photoassimilates due to water and nutrient absorption. There was 0.79 positive correlation between the fresh shoot matter and the root system volume. The reduced root system volume in soils containing high $\mathrm{Cu}$ concentrations can be a mechanism used by plants to reduce the area of contact with the $\mathrm{Cu}$ ions in the soil in order to limit absorption. Consalter et al. (2013) have found that Brachiaria decumbens is an $\mathrm{Al}$ accumulating plant, whose shoot is not affected by these elements' presence; however, there was root-thickening tendency in presence of Al.

The dry shoot matter was higher than the dry root system matter at all copper concentrations used in the current study. The concentrations 51.24 and 54.81 $\mathrm{mg} \mathrm{kg}{ }^{-1}$ have provided the lowest shoot and root system dry matter, respectively (Figure 8). The lowest biomass accumulations in the shoot and root system were found at similar concentrations, fact that indicates that brachiaria plants have limited the shoot and root system growth when they were cultivated in soil contaminated with $\mathrm{Cu}$ concentrations between 51.24 and $54.81 \mathrm{mg} \mathrm{kg}^{-1}$. There was 0.85 positive correlation between dry shoot matter and dry root system matter.

Copper concentrations above $75 \mathrm{mg} \mathrm{dm}^{-3}$ have reduced the growth of jatropha plants (Chaves et al., 2010), as well as the quality of timbó seedlings (Ateleia glazioviana ail.). However, Silva et al. (2014) have found that copper doses did not influence the quality of Cassia seedlings, and that the genus Stryphnodendron was able to kept seedling quality when up to $300 \mathrm{mg}$ $\mathrm{kg}^{-1}$ copper was added to the soil. Fageria (2001) has found copper toxicity in soil treated with doses above $51 \mathrm{mg} \mathrm{kg}^{-1}$ for rice; $37 \mathrm{mg} \mathrm{kg}^{-1}$, for beans; $48 \mathrm{mg} \mathrm{kg}^{-1}$, for maize; $15 \mathrm{mg} \mathrm{kg}^{-1}$, for soybeans; and $51 \mathrm{mg} \mathrm{kg}^{-1}$, for wheat. The better growth and accumulation of biomass in seedlings of Ricinus communis L. was found in 40 $\mathrm{mg} \mathrm{L}^{-1}$ of $\mathrm{CuSO} 4$, and the largest copper content in seedlings was found at a concentration of $60 \mathrm{mg} \mathrm{L}^{-1}$ CuSO4 (Kang et al., 2015).

According to Fageria (2001), brachiaria plants' tolerance to $\mathrm{Cu}$ was close to that of rice, maize and wheat; however, this species has shown lower tolerance when it was compared to Jatropha, Cassia and Stryphnodendron plants. Thus, the phytoremediation of soils contaminated with high $\mathrm{Cu}$ levels requires prioritizing species such as Brachiaria decumbens, which present higher tolerance to copper.

\section{CONCLUSIONS}

The growth of Brachiaria decumbens plants varied according to the plants' age, as well as to the copper concentrations in the soil. Despite the 
influence copper concentrations have on plant growth, Brachiaria decumbens showed potential to be used in copper phytoremediation in soils contaminated with concentrations up to $45.52 \mathrm{mg} \mathrm{Kg}^{-1}$.

\section{REFERENCES}

ARROYAVE, C. et al. Differential aluminum resistance in Brachiaria species. Environmental and Experimental Botany, 89:11-18, 2013.

BEZERRA NETO, E.; BARRETO, L. P. Métodos de Análises Químicas em Plantas. Recife: Imprensa Universitária da UFRPE. 2004, 263p.

CARMO, M. L. et al. Seleção de plantas para fitorremediação de solos contaminados com Picloram. Planta Daninha, 26(2):301-313, 2008.

CHAVES, L. H. G. et al. Crescimento, distribuição e acúmulo de cobre e zinco em plantas de pinhão manso. Revista Ciência Agronômica, 41(2):167-176, 2010.

CONSALTER, R. et al. Efeito de doses de alumínio no crescimento e nutrição de Brachiaria decumbens cultivada em solução nutritiva. Cultivano o Saber, 6(3):98-112, 2013. Available in: <http://www.fag.edu.br/upload/revista/cultivando_o_ saber/526e669e783bb.pdf> Access in: February, 14, 2017.

FAGERIA, N. K. Adequate and toxic levels of copper and manganese in upland rice, common bean, corn, soybean and wheat grown on an oxisol. Communications in Soil Science and Plant Analysis, 32(9-10):1659-1676, 2001.

KANG, W. et al. Distribution and chemical forms of copper in the root cells of castor seedlings and their tolerance to copper phytotoxicity in hydroponic culture. Environmental Science and Pollution Research, 22(10):7726-7734, 2015.

$\mathrm{LI}$, J. et al. Copper pollution decreases the resistance of soil microbial community to subsequent dry-rewetting disturbance. Journal of Environmental Sciences, 39:155$164,2016$.

MARANHÃO, C. M. A. et al. Produção e composição químico-bromatológica de duas cultivares de braquiária adubadas com nitrogênio e sua relação com o índice SPAD. Acta Scientiarum. Animal Science, 31(2):117122,2009

SANTOS, J. V. et al. Biological attributes of rehabilitated soils contaminated with heavy metals. Environmental Science and Pollution Research, 23(7):6735-6748, 2016.

SANTOS, F. S. et al. Chelate-induced phytoextraction of metal polluted soils with Brachiaria decumbens. Chemosphere, 65:43-50, 2006.

SANTOS, M. E. R. et al. Características morfogênicas e estruturais de perfilhos de capim-braquiária em locais do pasto com alturas variáveis. Revista Brasileira de Zootecnia, 40(3):535-542, 2011.

SILVA, R. F. et al. Efeito do cobre sobre o crescimento e qualidade de mudas de Stryphnodendron polyphyllum Mart. e Cassia multijuga Rich. Ciência Florestal, 24(3):717725, 2014.

SILVA, R. F. et al. Crescimento e qualidade de mudas de Timbó e dedaleiro cultivadas em solo contaminado por cobre. Revista Brasileira de Engenharia Agrícola e Ambiental, 16(8):8811-886, 2012.

SONMEZ, S. et al. High level of copper application to soil and leaves reduce the growth and yield of tomato plants. Scientia Agricola, 63(3):213-218, 2006.

VELASCO, F. O. Valor nutricional da Brachiaria decumbens em três idades. Universidade Federal de Minas Gerais, Escola de Veterinária. 2011. 141p.

Williams, M. E. Plant Nutrition 3: Micronutrients and metals. The Plant Cell. 27(5):1-20, 2015.

YRUELA, I. Copper. In: BARKER, A. V.; PILBEAM, D. J. Handbook of plant nutrition. New York, USA. 2nd Edition. 2007, p.367-398.

ZANINE, A. M.; VIEIRA, B. R. Fluxo de tecidos em gramíneas. Revista Científica Eletrônica de Agronomia. N. 6, 2006. Available in: <http://faef.revista.inf.br/imagens_arquivos/arquivos_ destaque/F5NRCOYPXwKc4Yn_2013-4-29-17-52-12.pdf>. Access in: February, 13, 2017. 